\title{
Learner Support to Adult Students in Open Distance and Learning: University of South Africa Lecturers' Views
}

\author{
Baloyi Gezani P \\ Department of Adult Basic Education and Training \\ baloygp@unisa.ac.za
}

Doi:10.5901/mjss.2013.v4n13p555

\begin{abstract}
In today's learning society, student support in institutions of higher learning is a topical issue. The recent global growth and popularity of open and distance learning $(O D L)$ has been attributed to the unique advantages of this form of learning (e.g. flexibility for those students who wish to combine a working life with further studies). Moreover, ODL is an effective tool in enabling students from less privileged social groups to participate in learning. These students are often unreachable owing to their geographical location or they are unable to access higher education for a variety of reasons, such as financial constraints or domestic arrangements. In the light of all this, in this article, I will investigate lecturers' views on learner support in the Department of Adult Basic Education and Training (ABET) at the University of South Africa (Unisa), the largest, dedicated ODL institution in South Africa. A review of literature study identified the Community of Inquiry model proposed by Garrison, Anderson and Archer (2001) as useful in this context and this model will be used as the conceptual framework for this study. The researcher will use a qualitative approach in interviewing lecturers in the ABET department. The lecturers are of the opinion that learner support systems are a vital tool in teaching and reaching out to students. The literature review suggests that the distance between the university and the student still has to be reduced more to ensure that student support reaches all students on an equal basis. The purpose of this study is to seek to add new knowledge to our existing body of knowledge concerning student support.
\end{abstract}

Keywords: Open Distance Learning (ODL), University of South Africa (Unisa), Learner Support, Adult Basic Education and Training (ABET), Online learning

\section{Introduction}

The concept of Open and Distance Learning (ODL) is very broad and can be defined in a number of ways, which is why it is important to point out that there is no single, all-embracing definition of this concept. Freeman (2004:6) defines ODL as an amalgamation of two approaches that focus on expanding access to learning. Moon, Leach and Stevens (2005: 218) define ODL as consisting of a number of open learning approaches which, when combined with distance education methodologies, are often referred to collectively as open and distance learning. According to the Commonwealth of Learning (2000) ODL is: "correspondence, home study, independent learning ... flexible learning or distributed learning" In ODL philosophy and practice, ODL represents approaches that focus on opening access to education and training provision, approaches that free learners from the constraints of time and place, and that offer flexible learning opportunities to individuals and groups of learners (Unesco 2002: 7). Common elements on which many authors agree in their definitions of ODL are the combination of Distance Education (DE) and Open Learning, and the issue of access and separation between the lecturer and the learner.

This paper investigates the provision of learner support in the Adult Basic Education and Training (ABET) programme at a specific university, the University of South Africa (Unisa). Extensive literature has been reviewed on the development of $\mathrm{ODL}$ as a mode of higher education provision, the characteristics of ODL, the rationale for ODL provision, the use of Information Communication Technology (ICT) in ODL, learner support in ODL and the state of ABET in the South African and Unisa context.

ODL students often feel isolated. Boyle et al (2010: 122) state that there are specific, pressing issues in the distance learning environment: students often report feelings of isolation, feel that they experience little sense of connection and belonging, and find it difficult to maintain engagement in, and motivation for, learning.

Learner support is a broad concept and one that can be viewed from different angles. Garrison and Brynton (1987), Tait (1995) and Thorpe (1998 in Lee (2003: 182) define learner support as a rather broad concept and its definition varies from one researcher to another. Some consider resources and interactivity as critical in defining learner 
support, while others put more emphasis on individualisation or the customisation of services.

Against this background, this paper investigates Unisa's ODL system with specific reference to the provision of learner support and an ABET programme.

\section{Conceptual Framework of this Study}

This study is a descriptive and interpretive case study on learner support in the specific ODL context for ABET programme. The Community of Inquiry (Col) model, originally proposed by Garrison, Anderson and Archer (2000), served as the conceptual framework for the study. The researcher used this model as a guide for the empirical study and categorised the qualitative questions to answer the research questions.

\section{The Problem Statement}

The importance of learner support in ODL is crucial and many of the scholars referred to above argue that it has a role to play in increasing the success rate of ODL students. The ABET department is grappling with student support at Unisa (which currently has a high failure rate).

This prompted the researcher to explore the perceptions, views, opinions, and attitude of ABET lecturers on the use of learner support structures. The learner support structures at Unisa depend on Information Communication Technology (ICT), tutorial classes, group discussion classes, etc. Given this, the researcher wants to address the following question in this study:

- What are Unisa ABET lecturers' experiences of learner support systems?

\section{Significance of the Study}

In the light of the background given above, the study is significant for the following reasons. The literature reviewed indicates that ODL focuses on removing barriers to access to higher education; this is particularly important for disadvantaged students who live in rural areas - for these students, learner support is central to student success (Badat 2005; Thorpe 2001; Dzakira 2005; Kelly and Mills 2007). The study paid particular attention to learner support through elearning in general and makes suggestions concerning the appropriate use of ICT in providing learner support to ODL. I believe that this study will add to our body of knowledge concerning ODL student support and promote scholarly debate on this issue.

\section{Findings and Discussions}

In this section, I shall discuss key thematic areas that emerged during the interviews with the participants and the subsequent analysis of the transcripts. The section is organised as follows: (1) an explanation of the interlinking themes that emerged from the data, (2) an interpretation of the findings, and (3) the conclusion.

The themes that emerged during the interviews demonstrate very clearly that learner support in the ABET Department is crucial in ensuring learner success. Several codes were identified during the analysis of the data. These were then clustered into code families. Each of the themes and related issues have been analysed to demonstrate their relevance to the research question

Interlinking themes that emerged from the data are as follows: student context, computer literacy, accessibility of Unisa's learner support systems, and motivation and time. Each theme is briefly explained.

\section{Student Context}

Unisa is an ODL institution that functions in an environment in which its students live at various geographical distances from Muckleneuk (where the main campus is based). The students who are enrolled in the university, including those enrolled as ABET students, come from different socio-economic backgrounds and from different areas of South Africa (rural and urban). Note that teaching and learning resources in the rural areas are generally of a lower standard compared with those available in urban areas. The method of teaching can, however, reach students who live in urban, semi-urban and rural areas.

Asked to tell about their experiences, this is what one of the lecturers has said: 
"It is yourself and the studies and you have to do it for yourself, you have to be serious about what you want to know. There was somehow a distance between the students and lecturers."

The purpose of student support is to guide and support students in a way that enables them to succeed in their studies. University education seems to be a challenge to the variety of ABET students, most of whom come from rural areas, areas that are characterised by poor teaching and learning resources.

\section{Computer literacy}

The researcher asked the participants about e-learning because learner support depends on ICT. The respondents gave various interpretation of e-learning as follows:

"E-learning to me means we have to teach online. We have to prepare whatever learning activities put our modules online engage with the students as in the classroom that is what it means to me".

"It means the students can access the information related to their studies online."

Others defined it as follows:

"I think it is electronically any medium through any medium, the computer but also other technologies like cell phones, all about e-learning, the use of technology to learning something."

"We are talking about technology. How do we integrate technology for teaching and learning activities? Involves technology and teaching in various forms, for example, at Unisa we do have the whole thing of using myUnisa. You have other means of social media like that are involved like Skype, Facebook and other things, I guess they follow under e-learning as well because those are some of the gadgets that one can use in getting through to students who are very far and that is my understanding of e-learning."

It was clear from what these lecturers said that the use of e-learning at Unisa is fairly new, and some of the lecturers do not have a comprehensive understanding of what e-learning or online learning is. This is an issue that Unisa should be aware of it. If lecturers do not have a good grasp of what e-learning or online learning is all about, perhaps it is too premature for us to expect them to use it effectively for teaching and student support purposes.

\section{Accessibility of Unisa's Learner Support Systems}

\section{1 myUnisa}

Of the ten lecturers interviewed, five are using myUnisa for teaching and learning activities (even though some of them have not started using the myUnisa, they have an understanding of what myUnisa can do for students, and they recognise that myUnisa brings the students closer to the department). However, they also acknowledge the fact that rural students do not have an access to the internet and other facilities. They understand the importance and the value of myUnisa. They see it as a networking tool and help to reduce the distance between the student and the institution.

The lecturers gave different views of the concept of myUnisa:

"myUnisa is providing the student with lots of advantages. Once their materials are from myUnisa, they can see their marks. They can form study groups, communicate with each other... the lecturers design forum groups where he can discuss, say, topic assignments and give feedback, find out how the students find the assignments. Things like that, then, feedback from the students can be used as an assessment tool."

It is clear that lecturers require more time to visit the discussion forums and respond to the questions asked by students. The students are also of the opinion that lecturers do not visit the discussion forum of myUnisa, and the lecturers interviewed for this study confirm the fact that they simply do not have the time to visit the discussion forums.

Some students have no internet access, and some find it too expensive to access the internet. And some students value personal communication. This is how they described their experiences: "I use myUnisa to communicate with my lecturer if I have difficulties. I manage to socialise with other students by using myUnisa." Students such as these should be encouraged to use the various learner support strategies in their learning activities to ensure that they succeed in their studies.

It is clear that lecturers require more time to visit the discussion forums and other functions of myUnisa. 
It is obvious from the responses that use is focussing on the group discussion and announcement therefore, it is important for Unisa to focus on the training of academics to focus on the functions that are not used frequently like additional resources, learning units, drop box etc.

\title{
8.2 Tutorials
}

The lecturers understood the concept of the tutor as follows:

"By the way like I have said we are an ODL institution so I think the system of tutor was to help the students actually to understand the content and they gather at a common venue and be grounded and supported with the learning content."

However, the lecturers see themselves having a role to play in tutoring.

\begin{abstract}
"Yes, I have a role because I am a primary lecturer I know what will become out in the examination so that I can lead in the teaching of any module, so I can guide. We need to establish the partnerships with the tutor because he or she is doing what I am not able to do because of the distance. That is why I say I am missing a link that is not there."
\end{abstract}

Of the ten lecturers interviewed, six feel that the tutor system has a role to play in supporting students in the department. Five of the ten lecturers confirmed that their modules are tutor linked and only one lecturer was unsure whether or not there were tutor-linked modules. Some indicated that they did know the tutors who helped students with tutorial classes.

\subsection{Group discussion classes}

The lecturers were asked to share their experiences of attending group discussion classes.

Group discussion classes have not been conducted since the ABET became a Department. Group discussion classes could supplement the other learner support systems provided by the Department. Most lecturers interviewed agree that group discussions have a role to play in increasing throughput rates and success rates. In short, the lecturers interviewed for this study have positive attitudes towards group discussion classes.

One participant differed with from his/her colleagues:

"ABET group discussions have not been held because of the number of lecturers that are few, the students being in multitudes. We last went for group discussions in 2009 and it was chaotic when we were in Durban because the students were very many and you can see the hunger that the students had to discuss with lecturer. For me, group discussions are the way to go."

\subsection{Video conferencing}

At present, there is a strong awareness at Unisa about the importance of video conferencing as a means of reducing the distance between the students and the university.

Of the ten lecturers interviewed, seven have used video conferencing. This is how these lecturers described their experiences: they claimed that the students were not active during the sessions, and this resulted in an absence of twoway communication. In one case, the lecturer had to change his teaching style to suit the student's needs or level. Another lecturer used the term "horrible" to describe the session. Some of the challenges or issues raised by this lecturer was that the students could not hear the lecturer properly and claimed that the lecturer talked too softly, too slowly or too quickly. In other words, some students were clearly unhappy about the lecturer's presentation. The lecturer raise the session lowly and could not recommend it to the Department.

During the sessions, the researcher got the feeling that the lecturers had been trained on how to use video conferencing, that most of them liked it, and that they had access to it. Although the students were interested in video conferencing and indicated, during the interviews, that they found it useful, they all claimed it would not work well in the centres (which are in the cities and towns), that they will find it useful during the interviews, they will find it difficult to go to the centers in the cities and towns. Most ABET students in the rural areas lack internet access, which means that these students will find it difficult to obtain access to a video conference. However, participants definitely felt that video conferencing has potential: this was confirmed in both the questionnaire and the interviews. 


\section{Motivation}

Students have different reasons for studying at the ABET Department. These reasons include cheap fees and the flexible mode of learning delivery. Like all students, these students will need to be self-motivated if they are to succeed in their studies at Unisa.

\section{Time}

One issue that became clear was that students did not budget time for their learning activities. Furthermore, as far as the average student's environment was concerned, learner support systems were lacking. The College of Education has noted that, in spite of the use of ICT in learner support, facilities are under-utilised by lecturers themselves. When the lecturers use learner support systems, they should bear in mind that some students do not have access to these systems and they should therefore provide tutorial letters to fill in this "gap". Although the digital divide is real and exacerbates the information gap, technology can become the force that will provide equitable access to educational for all, regardless of location or social and economic circumstances (Block 2010).

\section{Conclusions}

The conclusion is based on the themes that emerged from the data analysis of the interviews.

The data collected indicated that Unisa assumes that both its students and lecturers possess the competencies required to use computer facilities; however, this is not always the case. Training is therefore needed to equip lecturers with the skills they need to use computer facilities; to this end, lecturers should be encouraged to attend Unisa training programmes in ICT and learner support.

Indeed, the challenges presented by ICT should be given attention as a matter of priority, because these challenges, if left unaddressed, will soon have a detrimental impact on the effectiveness of student support systems in the ABET Department.

The accessibility of learner support structures (e.g. the internet) was a cause for concern. The distance between the students and lecturers could be addressed, but only if students have access to the internet. Additional support in the form of tutorials should still play a major role in supplementing teaching and learning activities. Communication and collaboration between the lecturers and the students were lacking owing to the unavailability of proper learner support facilities. Furthermore, most students have not acquired basic English language skills and struggle to express themselves. However, some students are technologically literate.

The data analysis showed that most lecturers have not made full use of myUnisa for teaching and learning. However, this is partially because the university has not yet gone fully online. Furthermore, the majority of lecturers are not motivated to use myUnisa for a number of reasons (e.g. they do not have time, and at present myUnisa is limited to specific functions).

The student is always at the centre of what the university or ODL institution should do. The ABET Department should move to the next level and discontinue any outdated pedagogical practices. Unisa's ODL policy aims to see students embark on the new culture of learning. The ABET Department has to seriously consider other forms of learner support, ones that will be learner centred. (For example, video conferencing, which is still under utilised, remains unfeasible simply because of the challenges mentioned by the students and the lecturers.)

\section{References}

Badat, S. (2005). South Africa: Distance higher education policies for access, social equity, and social and economic responsiveness in a context of the diversity of provision. Distance Education, 26(2): 183-204.

Boyle, F., Kwon J, Ross C. \& Simpson O. (2010). Student- student mentoring for retention and engagement in distance education. Open Learning, 25 (2): 115-130.

Brindley, J.E, \& Paul, R. (2004). The role of learner support in institutional transformation-A case study in the making. In J.E. Brindley, C, Walti, \& Zawacki-Richter (Eds), Learner support in open, distance and online learning environments, Oldenburg : Bibliotheksund Informationsystem der Universitat Oldenburg : 39-50.

Department of Education. (2001). The National Plan for Higher Education. Pretoria: Government Printers.

Dzakiria, H. (2005). The Role of Learning Support in Open and Distance Learning: Learner's experiences and perspectives. Turkish Online Journal of Distance Education, 6(2): 1-14.

Garrison, D. R., Anderson, T. \& Archer, W. (2000). Critical Inquiry in a Text-Based Environment: Computer Conferencing in Higher 
Education. The Internet and Higher Education, 2(2-3): 87-105.

Kelly, P. \& Mills, R. (2007). The ethical dimensions learner support. Open Learning, 22(2):149-147. New York: Routledge.

Moon, B., Leach, J. \& Stevens, M. (2005). Africa Region Human Development. Working papers Series 104. Designing Open and Distance Learning for Teacher Education in Sub-Saharan Africa: A toolkit for Educators and planners. Geneva: The World Bank. Tait, A. (2000). Planning Student Support for Open and Distance Learning. Open Learning, 15(3): 287-299.

Thorpe, M. (2002). Rethinking learner support: The challenge of collaborative online learning. Open Learning, 7(2): 105-119.

UNESCO. (2002). Open and Distance Learning: Trends, Policy and Strategy Considerations. Paris: UNESCO. 